\title{
Pembuatan Paket Tutorial Batik Ikat (Tie Dye) bagi Pelajar Sekolah Dasar Kelas 3-5 Guna Memperkenalkan Batik Ikat dan Meningkatkan Kreativitas Anak
}

\author{
Aria Weny Anggraita ${ }^{1}$, Nanik Rachmaniyah ${ }^{2}$, Budiono $^{3}$, Okta Putra4 \\ ${ }^{1234}$ Departemen Desain Interior, FDKBD, Institut Teknologi Sepuluh Nopember, Surabaya \\ ${ }^{1}$ aria.weny@interior.its.ac.id, aria.weny@yahoo.com
}

\begin{abstract}
ABSTRAK
Pembuatan paket tutorial batik ikat bertujuan berbagi ilmu dengan para pelajar SD untuk lebih mengenalkan keunikan dan keindahan batik ikat. Paket ini ditujukan kepada pelajar SD kelas 3-5 yaitu anak usia 9-11 tahun sebagai target utama, melihat dari kondisi School from home (SFH). Pelajar SD yang sangat aktif dengan berbagai kegiatan diluar rumah baik dari sekolah ataupun dari kegiatan ekstra diluar sekolah, saat ini harus tetap tinggal dirumah dan belajar dirumah karena adanya wabah atau pandemi Covid-19. Mengapa batik ikat dan bukan batik tulis, alasan utama adalah karena teknik batik ikat lebih mudah dibandingkan dengan batik tulis, batik ikat juga memiliki bahan yang sederhana, batik ikat juga mudah dikreasikan. Dengan adanya paket tutorial batik ikat, kami berharap dapat mengenalkan batik ikat lebih dini kepada para pelajar SD, dan bermanfaat dalam mengisi aktivitas mereka saat SFH. Paket tutorial ini berisi video tutorial cara membuat batik ikat, dan semua bahan yang dibutuhkan dalam membuat batik ikat. Pada paket juga akan dilengkapi dengan asesoris interior yaitu sarung bantal kursi, sehingga setelah sarung bantal kursi selesai di batik, pelajar dapat menata bantal tersebut pada salah satu ruang dirumah. Paket yang dibagikan akan dikemas dengan kemasan yang praktis dan handy.
\end{abstract}

Kata kunci: Batik ikat; Paket; Tutorial; Tie Dye

\section{ABSTRACT}

The making of traditional batik tutorial packages is intended to share knowledge with elementary students in order to enhance the batik uniqueness and beauty. The package is addressed to the 3-5 graders of 9-11 as a primary target, based on the condition of the school from home (SFH). An elementary school student whose very active with outdoor activities whether from school or from extra outside school, should stay and study at home because of an outbreak or a covid-19 pandemic. The main reason for choosing batik ikat is because the batik ikat technique is easier than the handwritten batik, the ikat batik also has a simple material, the ikat batik is also easy to create. With the batik ikat tutorial package, we hope to be able to introduce batik ikat early to elementary school students, and be useful in filling their activities during SFH. This tutorial package contains video tutorials on how to make batik ikat, and all the materials needed to make batik ikat. The package will also be equipped with interior accessories, it is a cushion cover, so that after the chair cushion cover is finished in batik, students can arrange the pillow in one of the rooms in the house. The packs will be packed with handy, practical packages.

Keywords : Batik Ikat; Package; Tutorial; Tie Dye

\section{PENDAHULUAN}

Indonesia memiliki berbagai budaya dan kerajinan khas yang menjadi kebanggan dan identitas bangsa. Salah satunya adalah batik. Batik dapat diartikan sebagai kain bergambar yang dibuat secara khusus dengan menuliskan atau menorehkan malam (lilin) pada kain, kemudian pengolahannya diproses dengan cara tertentu (Wulandari,2011). Membatik dapat diartikan melukis pada kain. Sebenarnya batik dapat dibuat dengan bemacam-macam metode. Pada era modern saat ini batik tidak hanya ditulis, tetapi juga ada batik cap, cetak, print dan ikat. Saat ini juga telah banyak dibuat batik Eco, batik yang dibuat dari beberapa serat daun, 
disebut juga batik Eco Print. Macam-macam batik tersebut memilki kekhasan dan teknik pembuatan yang berbeda-beda. Diantara berbagai teknik pembuatan batik diatas, batik ikat adalah salah satu batik yang memiliki hasil yang khas dan mudah untuk dibuat. Bahan yang digunakan untuk batik ikat juga tidak banyak. Dalam membuat batik ikat, dengan bahan yang sama dapat menghasilkan banyak motif-motif yang beragam. Motif berbeda dihasilkan dari jumlah pengikatan dan area pengikatan atau pelipatan, dengan hanya merubah posisi ikatan dan jumlah ikatan maka akan terbentuk motif baru.

Adanya paket tutorial batik ikat, masyarakat dapat mencoba membuat batik sendiri dirumah atau dimana saja. Tutorial akan dibuat dengan simple dan mudah dipahami. Saat ini seluruh dunia sedang mengalami pandemic yang mengharuskan setiap warganya untuk tinggal dirumah saja. Pada keadaan pandemic seperti ini seluruh kegiatan akan dikerjaan dan diselesaikan dari dirumah. Bagi pelajar yang sedang School from Home (SFH) tentunya para pelajar sangat membutuhkan aktivitas yang bermanfaat dalam mengisi waktu belajar dirumah. Latar belakang tersebut mengawali ide dibuatnya paket tutorial batik ikat (tiedye) bagi pelajar SD. Paket tutorial ini ditujukan utamanya untuk pelajar SD kelas 3-5. Pelajar SD yang sangat aktif dengan berbagai kegiatan diluar rumah baik dari sekolah ataupun dari kegiatan ekstra diluar sekolah, karena SFH mereka harus tetap tinggal dirumah dan belajar dirumah karena adanya wabah atau pandemi COvid-19. Menurut Atmodiwiryo (2004) fase anak sekolah yaitu usia 6-12 tahun memerlukan beberapa ketrampilan, yaitu:
a. Self help skill
b. Social
c. help skill
d. Schoolskill yaitu penguasaan akdemik maupun non akademik. Termasuk keterampilan dalam membuat prakarya.
e. Play skill

Pada beberapa ketrampilan yang harus dimiliki pelajar sekolah, terdapat ketrampilan school skill salah satunya adalah ketrampilanmembuat prakarya. Usia anak 9-11 tahun adalah usia keaktifan anak dan menyukai tantangan dan mencoba hal baru (Wijanarko 2018). Adanya paket tutorial batik ikat dengan interface yang fun dan easy learning, kami berharap pelajar usia sekolah memiliki ketrampilan dalam membuat prakarya dan dapat mengenalkan batik ikat lebih dini kepada para pelajar SD, dan melatih kreativitas pelajar dengan kegiatan bermanfaat untuk mengisi aktivitas saat $\mathrm{SFH}$.

Batik ikat adalah salah satu batik yang memiliki hasil yang khas dan mudah untuk dibuat. Bahan dan peralatan yang dibutuhkan untuk membuat batik ikat juga tidak banyak. Dalam membuat batik ikat, dengan bahan yang sama dapat menghasilkan banyak motif-motif yang beragam. Motif berbeda dihasilkan dari jumlah pengikatan dan area pengikatan atau pelipatan, dengan hanya merubah posisi ikatan dan jumlah ikatan maka akan terbentuk motif baru.

Sangat menarik dan bermanfaat bila dapat memperkenalkan pembuatan batik sejak dini kepada pelajar SD, mengingat batik adalah salah satu kerajinan bangsa Indonesia yang memiliki kekhasan lokal. Masa SD dengan usia 9-11 tahun adalah usia perkembangan dimana anak menyukai tantangan dan selalu ingin mencoba hal yang baru. Pada masa inilah anakanak membutuhkan ketrampilan dalam berkarya. Pengenalan terhadapa batik dan berlatih membuat batik akan memberikan added value dan meningkatkan kreativitas para pelajar SD. 


\section{METODE PELAKSANAAN KEGIATAN}

Pembuatan paket tutorial ini terdiri dari tahapan kegaitan sebagai berikut:

a. Tahapan studi pustaka. Studi pustaka tentang batik ikat, membuat contain tutorial tentang batik ikat, meliputi sejarah, perkembangan, teknik-teknik batik ikat, dll terkait dengan pembuatan batik ikat, membuat studi pustaka, dan praktek membuat batik ikat. Studi pustaka mengenai perkembangan psikologi anak usia madya (9-11 tahun).

b. Tahapan visualisasi, membuat ilustrasi grafis yang sesuai dengan karakter anak usia 911 tahun. Pemilihan warna, bentuk dan karakter. Pada proses editing video dan pembuatan packaging.

c. Tahapan pembelian bahan dan peralatan batik ikat. Bahan untuk latihan/ujicoba dan bahan peralatan untuk 20 paket tutorial.

d. Tahapan pembuatan video

e. Tahapan pembuatan packaging dan manual book dengan infografis yang sederhana dan easy learning. ilustrasi grafis disesuaikan dengan karakter usia 9-11 tahun

f. Tahapan ujicoba sebelum paket disebarkan. Menganalisa kekurangan dan memperbaiki/menyempurnakan paket tutorial.

g. Menyebarkan paket kepada pelajar kelas 3-5 SD sebanyak 15-20 paket.

\section{PROSES PEMBUATAN PAKET TUTORIAL}

Proses awal kegiatan pembuatan batik ikat adalah mencoba beberapa teknik batik ikat dan mencoba beberapa pewarna. Selanjutnya dilanjut dengan pembuatan karakter anak SD sebagai karakter yang digunakan pada video tutorial. Setelah fix karakter yang sesuai, maka dilanjutkan dengan membuat video sejarah batik ikat di dunia dan membuat manual book.

\section{A. Proses Percobaan Pewarna Batik}

Pewarna yang dicoba adalah menggunakan pewarna dingin remasol, sumba makanan, dan pewarna sintetis unt pakaian yaitu wantex (pewarna panas). Dari percobaan penggunaan warna. Menggunakan sumba makanan, motif batik tidak terbentuk. Percobaan menggunakan pewarna sintetis remasol motif ikatan terbentuk tetapi banyak kegagalan yang terjadi, motif ikatan tidak tajam terbentuk, warnanya masih membaur. Berikut hasilnya:

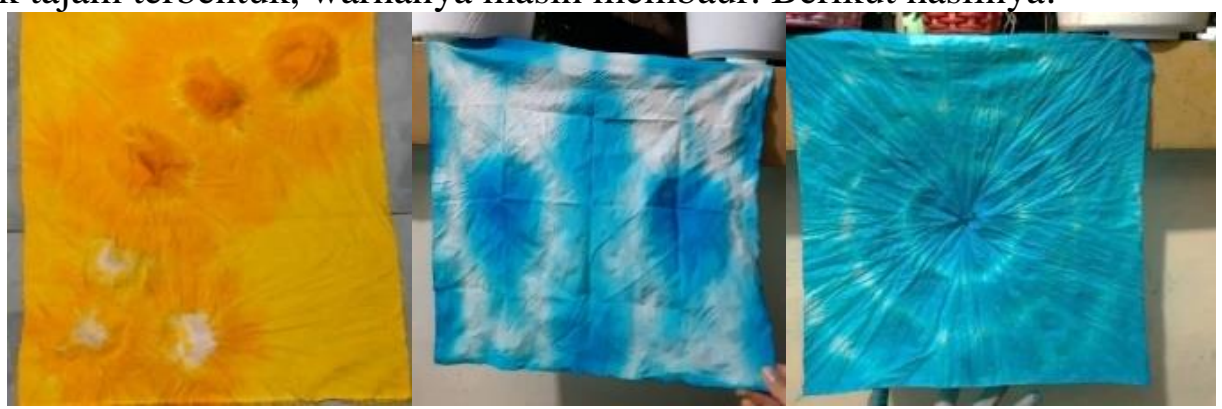

Gambar 1. Hasil batik menggunakan pewarna remasol (gagal)

Menggunakan warna sumba makanan, hasilnya warna tidak membentuk motif serat ikatan, tetapi pinggiran warnanya terlalu tajam tanpa bentuk yang jelas, bagian pinggir warna terlalu kaku, hasil percobaan sebagai berikut: 


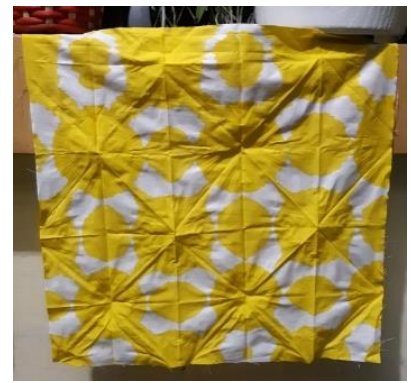

Gambar 2. Hasil batik menggunakan pewarna makanan (gagal)

Pada dasarnya pewarna remasol adalah pewarna batik ikat yang biasa digunakan pada industri kecil pembuatan batik tie dye, namun harus menggunakan bahan-bahan pendukung penguat warna seperti waterglass, sodium nitrit, soda ash. Untuk paket tutorial batik ini diusahakan bahan yang minimal dan mudah pembuatannya. Pembuatan batik ikat dengan remasol saja dan pewarna makanan, belum berhasil dilakukan, untuk itu perlu dicoba pewarna lainnya, yaitu dengan pewarna pakaian wantex. Menggunakan wantex motif ikatan lebih mudah terbentuk/terlihat. Hanya saja pewarna wantex adalah pewarna panas, akan lebih bagus bila pewarna direbus dulu dengan air panas. Pada pengabdian ini, kami mencoba beberapa cara penggunaan pewarna wantex:

a. wantex yang disiram air panas,

b. wantex yang awalnya disiram dengan air panas, dibiarkan dingin lalu dipakai sebagai pewarna batik ikat

c. dan wantex yang dicampur dengan air dingin

Hasil dari pewarnaan batik ikat dengan pewarna panas wantex proses a, b dan c, tidak ada perbedaan warna sebelum dicuci, namun ketahanan warna lebih bertahan pada pewarna yang menggunakan air panas atau kain dan pewarna direbus Bersama. Hasil pewarnaan sebagai berikut:

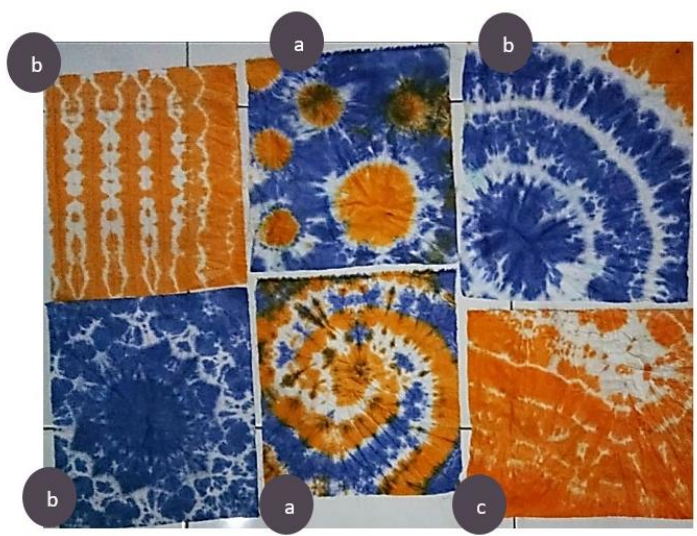

Gambar 3. Hasil batik menggunakan pewarna wantex

\section{B. Proses Pemilihan Teknik Pembuatan Motif Batik Ikat}

Pada proses pembuatan batik ikat banyak sekali teknik ikat yang bisa digunakan, bahkan diikat dengan bebaspun, tetap akan tercipta motif pada kain. Banyak sekali teknik dalam membuat motif pada batik ikat/tiedye, ada teknik ikat saja, teknik ikat dengan kelereng, teknik lipat dan ikat (shibori), teknik dengan jahitan. Pada video tutorial akan dipilih 4 teknik saja yang mudah untuk dipraktekkan pelajar kelas 3-5. Setelah mengkaji beberapa teknik dalam membentuk motif batik, 4 teknik yang mudah untuk dipraktekkan anak usia 9-11 tahun. Yaitu 
teknik ikat dan lipat. Teknik lipat dengan kelereng ataupun lipat bebas, berikut hasil percobaan dengan Teknik tersebut:

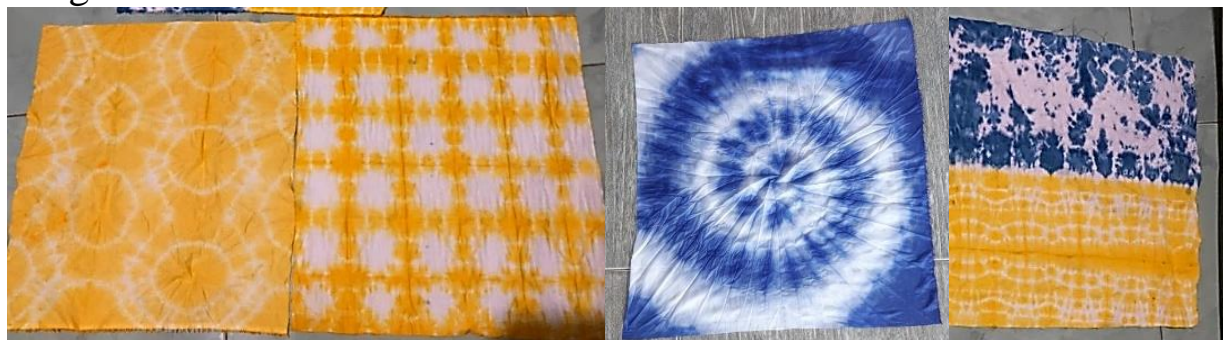

Gambar 4. Teknik ikat dengan kelereng,tanpa kelereng dan Teknik lipat

Beberapa teknik tersebut telah dicoba oleh anak usia 9 tahun, kendala yang dihadapi adalah saat menggunakan teknik ikat. Teknik ikat agak sukar dipraktekkan bila mengikat kain dengan menggunakan karet atau tali raffia. Untuk itu diperlukan alternatif material lain untuk mengikat. Ujicoba selanjutnya dengan menggunakan material kawat pita untuk souvenir ulang tahun. Anak usia 9 tahun mencoba mengikat kain dengan kawat tersebut, dan hasilnya lebih mudah daripada menggunakan karet dan tali raffia. Untuk itu pada paket perlu ditambahkan peralatan kawat pita sebagai alat ikat selain karet dan tali raffia.

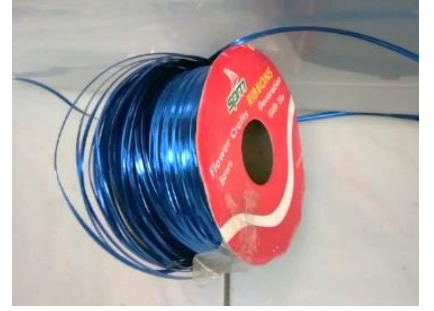

Gambar 5. Kawat pita, sebagai alat pengikat kain

\section{Proses Pembuatan Karakter Anak SD dan Video Tutorial}

Pada tahapan ini, langkah awal yang dilakukan adalah melakukan studi terhadap karakter warna bentuk tulisan yang sesuai dengan usia 9-11 tahun. Kajian mengenai infografis yang menarik bagi anak usia 9-11 tahun. Sejarah batik tiedye dunia. Pada video terdapat 3 informasi utama yaitu:

a. Sejarah singkat batik ikat

b. Teknik pembuatan

Pada menu ini, terdapat pilihan 4 teknik batik ikat yang akan ditunjukkan satu persatu teknik dan contoh hasil tekniknya, sehingga siswa bisa langsung memilih teknik mana yang akan dicoba

c. Aplikasi batik ikat sebagai asesoris interior, contohnya pada cushion, yang dapat memberikan sentuhan local pada suasana ruangan

Kajian mengenai infografis anak usia 9-11 tahun diperoleh hasil font yang menarik dan sesuai dengan usia 9-11 tahun, sebagai berikut: 
Aria Weny Anggraita ${ }^{1}$, Nanik Rachmaniyah ${ }^{1}$, Budiono ${ }^{1}$, Okta Putra ${ }^{1}$

Pembuatan Paket Tutotial Batik Ikat (Tie Dye) bagi Pelajar Sekolah Dasar Kelas 3-5 Guna

Memperkenalkan Batik Ikat dan Meningkatkan Kreativitas Anak

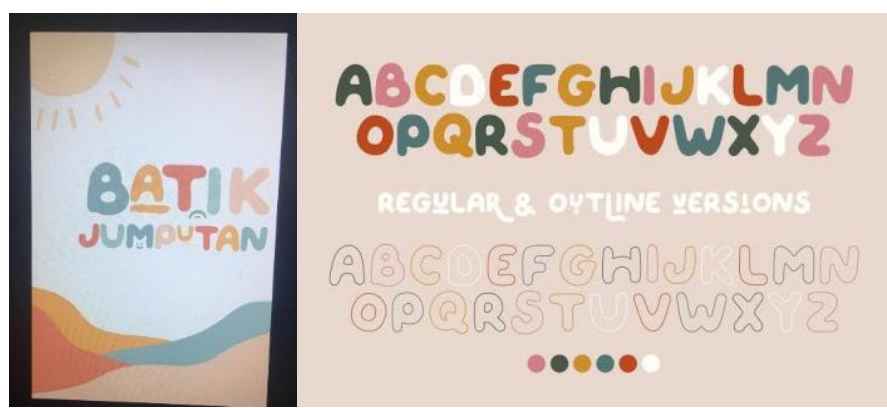

Gambar 6. Jenis font yang akan digunakan pada video tutorial

Tahap selanjutnya adalah membuat karakter anak SD yang ceria dan sebagai sosok teladan siswa. karakter yang terpilih sebagai berikut:

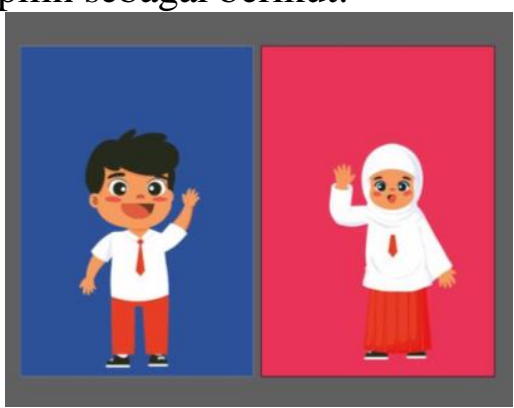

Gambar 7. Karakter Siswa SD yang sesuai dengan usia 9-11 tahun

Tahapan selanjutnya membuat animasi mengenai sejarah batik ikat. Animasi ini dibuat berdasar kajian mengenai bagaimana menyampaikan informasi yang menarik terhadap anakanak, dengan karakter warna dan jenis gambar yang telah disesuaikan. Bersamaan dengan pembuatan animasi ini, kami membuat video tentang pembuatan batik ikatnya, dan mendubbing suaranya.

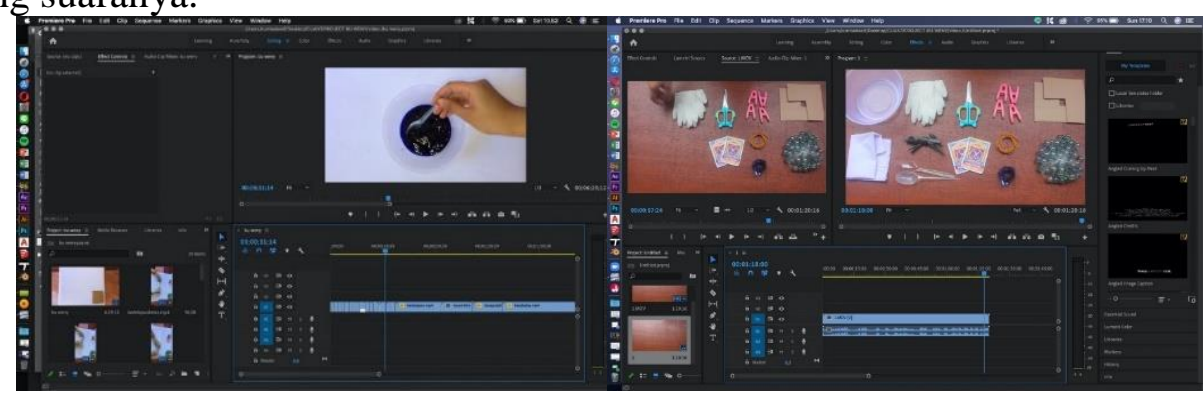

Gambar 8. Proses pembuatan video tutorial

Pembuatan animasi sejarah batik ikat, sebagai berikut:

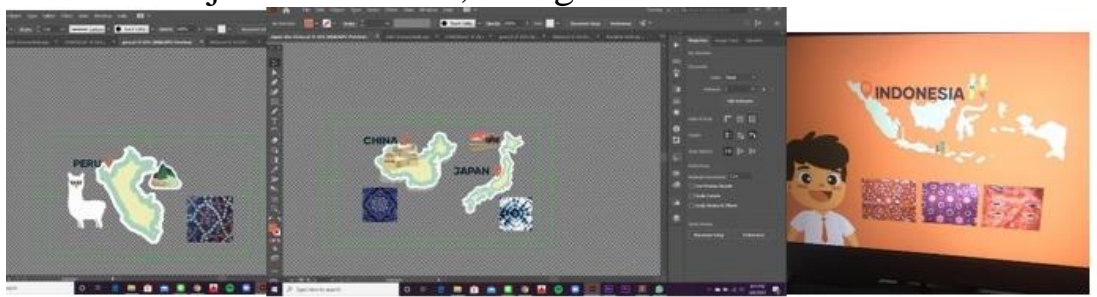

Gambar 8. Animasi Sejarah Batik Ikat 


\section{HASIL PAKET TUTORIAL}

Paket ini terdiri dari 2 box yang berisi peralatan membatik dan kain mori, panduan untuk membuat batik ikat berupa video yang dapat diakses melalui QR code dan buku manual sederhana. Selain paket tersebut kami juga berikan sarung bantal beserta bantal kursinya sebagai asesoris interior. Pelajar berlatih membatik pada sarung bantal kursi yang nantinya bisa ditata disalah satu ruang dirumah, sehingga pelajar akan merasa senang dan bangga dengan hasil karya buatannya sendiri yang dapat melengkapi asesoris interior rumahnya. Berikut bentuk paket tutorial yang akan diberikan pada 20 Pelajar SD kelas 3-5 usia 9-11 tahun:

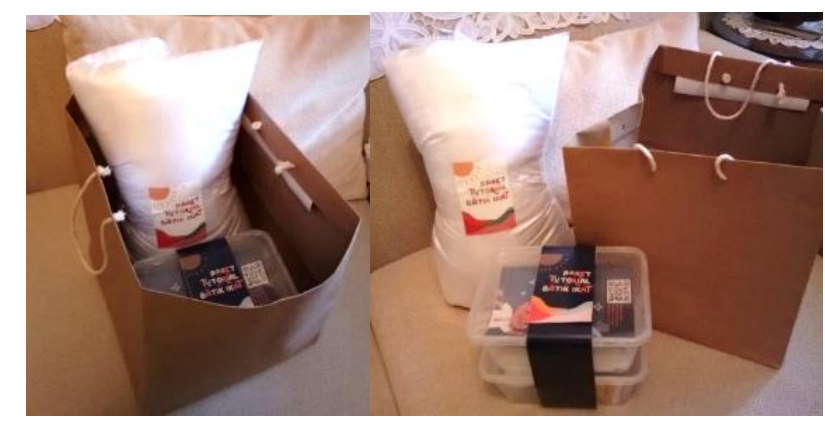

Gambar 9. Paket Tutorial batik ikat

Pada paket ini terdapat 2 box container 1000 lt, yang dapat digunakan sebagai wadah untuk proses pewarnaan batik, setelah selesai sisa pewarna dapat di pindah ke botol mineral kecil, dan wadah pewarna dapat dicuci kemudian digunakan kembali untuk menyimpan bahan dan peralatan membatik. Berikut foto paketnya:

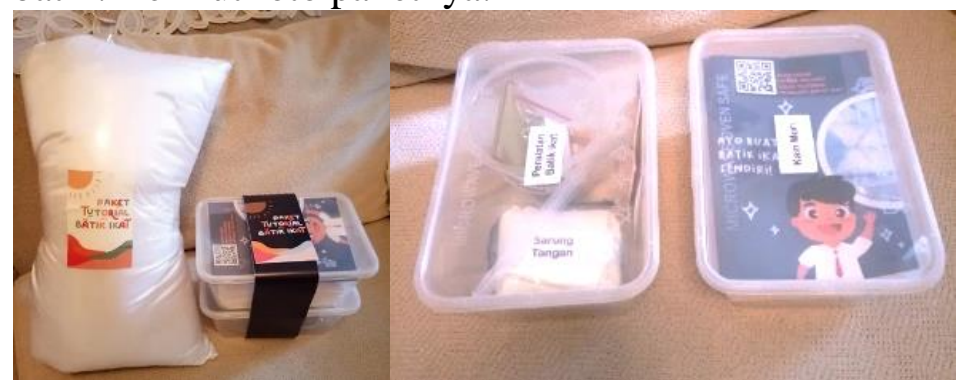

Gambar 10. Paket Tutorial batik ikat, 2 kontainer dan bantal kursi

Box pertama berisi panduan membuat batik ikat dan kain mori sebanyak 6 lbr ukuran $35 \times 40 \mathrm{~cm}$, digunakan untuk berlatih trial and error membuat batik ikat. Pada buku panduan terdapat QR code yang dapat di scan menuju link video tutorial pembuatan batik ikat, versi video akan lebih mudah dimengerti Pelajar usia 9-11 tahun. Menggunakan QRcode kami rasa lebih praktis dan mudah, karena HP siswa saat ini bisa secara langsung scan kode tersebut. Berikut kode QRcodenya:

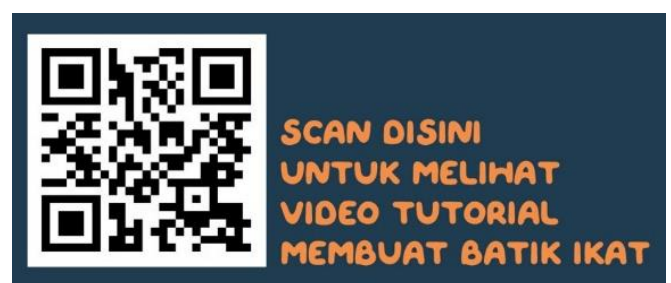

Gambar 11. QR code video panduan membuat batik 
Isi dari buku panduan pada paket ini adalah ringkasan proses pembuatan batik ikat menggunakan 4 teknik ikat, dan penjelasan alat dan bahan-bahan yang dibutuhkan. Berikut print out panduannya:

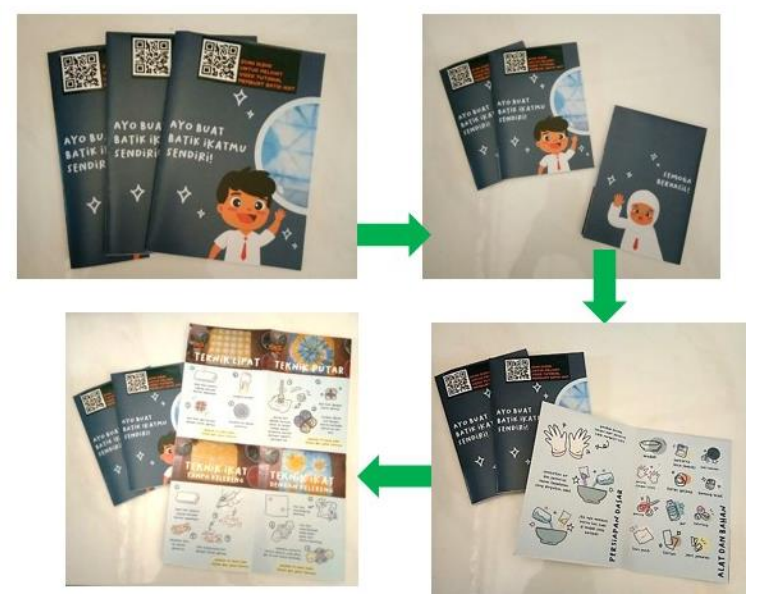

Gambar 12. manual book, yang terdapat pada paket

Isi dari box 1 kain mori dan box 2 peralatan batik ikat, berisi sebagai berikut:

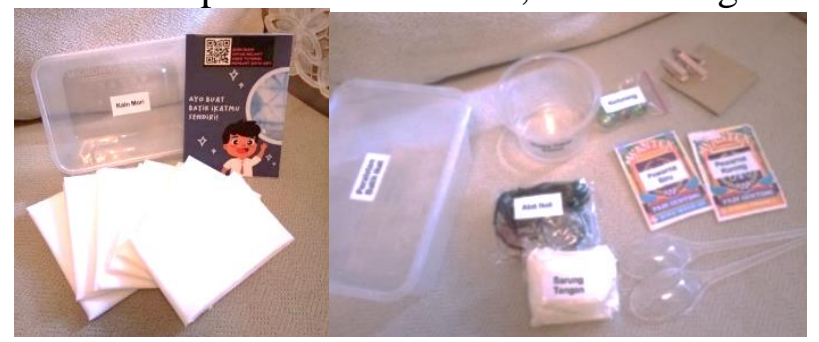

Gambar 13. isi 2 container: peralatan batik dan kain mori

6 lembar kain mori ukuran $35 \times 40 \mathrm{~cm}$ digunakan untuk berlatih membuat batik ikat. Bila sudah berhasil maka pelajar dapat mencoba membuat motif batik ikat pada sarung bantal. Paket tutorial batik ikat ini kemudian akan dikirimkan ke 15-20 Pelajar kelas 3-5 SD usia 9-11 tahun, untuk mengisi kegiatan SFH dengan melatih kreativitas dan keterampilan mereka.

\section{PEMBAGIAN PAKET TUTORIAL DAN PRAKTEK PEMBUATAN BATIK OLEH PELAAR KELAS 4}

Paket tutorial ini telah diberikan ke 15 pelajar usia 9-11 tahun. Paket diberikan kepada pelajar SD di Surabaya yaitu SD AlAzhar Kelapa Gading, SD Al Azhar 11, SDIT Al Uswah, SD Kreatif Muhammadiyah 16, dan SD Jurangombo Magelang.

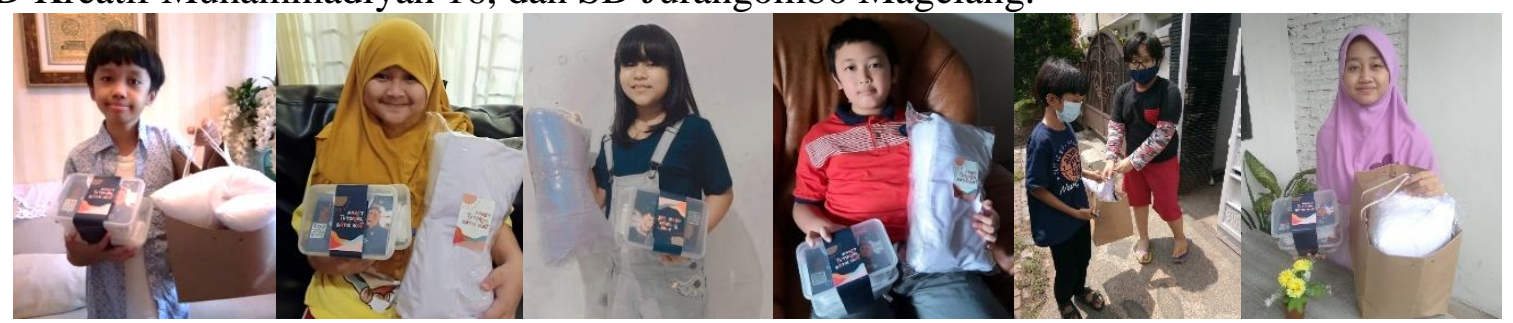

Gambar 14. Paket diberikan kepada Pelajar usia 9-11 tahun

Berikut hasil paraktek pembuatan batik ikat oleh salah satu pelajar kelas 4 SD menggunakan peralatan dan bahan yang disediakan pada paket tutorial batik ikat: 

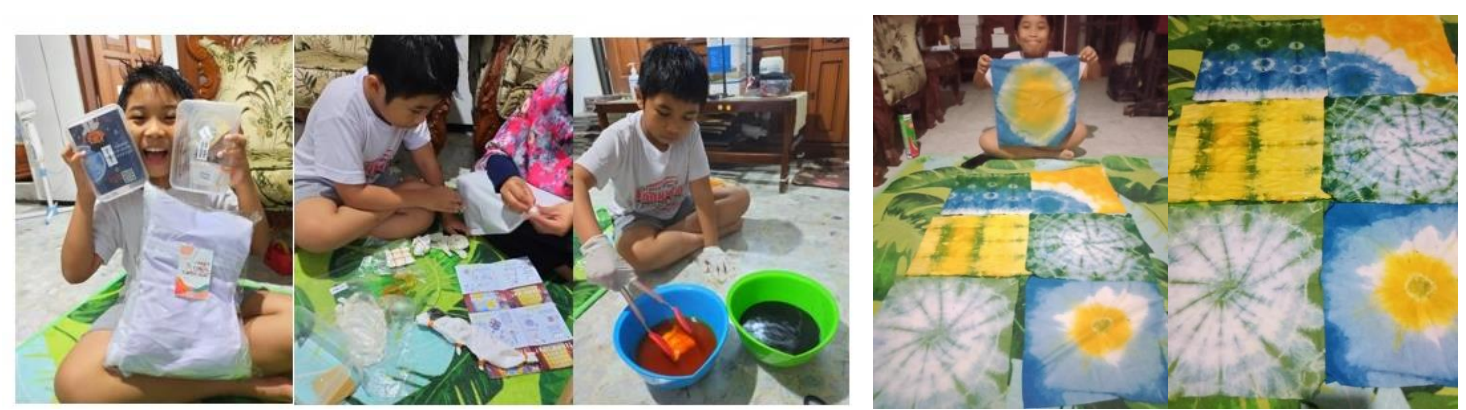

Gambar 15. Proses pembuatan dan Hasil batik ikat oleh pelajar usia 9 tahun

Hasil dari feedback orang tua, dalam percobaan membuat batik ikat tidak terlalu tampak kendala yang spesifik. Hanya saja buku panduan masih terlalu acak, infografis sedikit membingungkan. Saran orangtua, buku panduang dibuat perhalaman kecil sehingga langkahlangkahnya tidak terbalik. Untuk video sudah cukup jelas dan menarik

\section{KESIMPULAN}

Peket tutorial ini dibuat untuk mengisi kegiatan pelajar kelas 3-5 tahun terutama dimasa pandemic. Paket tutorial ini memberikan aktivitas baru yang dapat melatih kreativitas anakanak usia 9-11 tahun. Dengan belajar membuat batik ikat siswa dapat berkreasi dengan kain dirumah yang mungkin tidak terpakai dan ingin diperbarui, seperti kaos dirumah yang mungkin sudah bosan dengan warnanya, selain itu kain taplak meja dirumah juga bisa diperbarui, termasuk sarung bantal kursi (cushion), dll.

Kendala saat pembuatan paket tutorial ini adalah ketika memilih jenis pewarnaan yang mudah bagi siswa SD usia 9-11 tahun. Pewarna terpilih adalah pewarna panas sintetis wantex yang dapat disiram dengan air panas terlebih dahulu agar warna lebih menempel, atau langsung dengan air biasa. Pewarna jenis ini lebih mudah membentuk morif ikatan pada kain, dibanding pewarna remasol. Selain memilih pewarna kendala lainnya adalah pemilihan Teknik yang mudah bagi anak usia 9-11 tahun. Beberapa Teknik telah dicoba oleh anak 9 tahun. Teknik yang bisa dikerjakan adalah ikat dengan kelereng dan Teknik lipat, ikatan yang dihasilkan memang tidak terlalu kuat. Pada paket tutorial ini jenis ikatan yang disediakan ada 3 pilihan yaitu karet, tali raffia, dan kawat hias. Anak 9 tahun sebagai sampel memilih menggunakan kawat hias. Karena dirasa lebih mudah. Kendala lainnya saat membuat video tutorial lebih kepada masalah teknis dan lamanya waktu untuk brainstorming ide tampilan karakter pada video. Kendala lainnya adalah video yang diberikan, msh belum bisa berinteraksi langsung dengan penggunanya. video yang diberikan masih satu arah. Harapannya kedepan dapat membuat video sebagai aplikasi yang dapat berinteraksi dengan pelajar usia 9-11 tahun sebagai penggunanya. Pelajar dapat memilih menu-menu yang ada pada aplikasi.

\section{DAFTAR PUSTAKA}

Gunarsa, Singgih, 'Psikologi Perkembangan Anak dan remaja' PT. BPK Gunung mulia, Jakarta 2008

Ramadian, syafil, Childrencafe.com 'memilih aktivitas sesuai minat dan bakat' 2017

Utomo Wijanarko, Childrencafe.com 'ciri-khas-perkembangan-anak-usia-9-11-tahun' 2018

Wulandari,ari, 'Batik nusantara: Makna Filosofis, cara pembuatan, dan industry batik' penerbit, Andi Yogyakarta 2011

http://batikeraton.blogspot.com/2011/05/pewarnaan-batik.html 
Aria Weny Anggraita ${ }^{1}$, Nanik Rachmaniyah ${ }^{1}$, Budiono $^{1}$, Okta Putra $^{1}$

Pembuatan Paket Tutotial Batik Ikat (Tie Dye) bagi Pelajar Sekolah Dasar Kelas 3-5 Guna

Memperkenalkan Batik Ikat dan Meningkatkan Kreativitas Anak 